Yet it interposes an impassable obstacle to the ultra-violet rays, at least to those of shorter wavelength than about 2900 angstroms. It cuts off the iron spectrum at about the same point where the solar spectrum ends. Speaking roughly and generally, it may be said that glass is somewhat more opaque than ozone-i.e. that with diminishing wave-length the limit of transmission is reached somewhat sooner. To make a statement of this kind quite definite the thickness must of course be specified.

Sir William Huggins devoted a great deal of attention to the spectra of the sun and stars in the extreme ultra-violet region, using for the purpose a reflecting telescope, and prisms and lenses made of quartz or Iceland spar. In this way the absorption of a glass objective was avoided. $\mathrm{He}$ noticed in 1890 that the spectrum of Sirius showed a number of bands near the extreme limit of atmospheric transmission, the bands tailing off into complete absorption.

These bands were observed and discussed by other authors, but no definite conclusion was reached as to their origin until 1917 , when the matter was taken up by my colleague, Prof. Fowler, and myself. Our interest was stimulated by an excellent photograph of the bands, taken at Edinburgh Observatory under Prof. Sampson's direction, which I show on the screen. We found that the same bands were present in the solar spectrum. It may seem. strange that this had not been observed long ago, considering how closely the solar spectrum has been scrutinised for more than a generation. As a matter of fact this is one of the cases where a powerful instrument is a positive disadvantage. The bands are diffuse, and under high dispersion they are unrecognisable. In any case, they are less conspicuous than in the spectrum of Sirius, because in the sun numerous metallic lines are superposed upon them and distract the eye.

Now the position and general aspect of these bands suggested that they were connected with the absorption which terminates the spectrum. This led us to suspect that they were due to ozone, and the suspicion was readily confirmed by experiment. Burning magnesium ribbon gives a convenient source of continuous spectrum in the ultra-violet region. Interposing a long tube containing ozone between the burning magnesium and the slit, a series of bands was photographed which exactly corresponded to those photographed in the solar spectrum with the same instrument, as you will see in the slide shown.

\section{Absence of Ozone near the Ground.}

We are then driven to the conclusion that the absence of short waves from the spectra of the sun and stars is due to absorption by terrestrial ozone. But it was not thought desirable to let the matter rest there. It is true that many attempts had been made to determine the (no doubt very small) quantity of ozone in air by chemical means, but with very conflicting results, because other constituents of air, such as oxides of nitrogen, are liable to produce reactions not unlike those of ozone. It seemed more satisfactory to test the absorbing power of air near the ground for ultra-violet rays, to which ozone is so opaque. $I$ used for this purpose a mercury vapour lamp in a quartz vessel, which is a powerful source of ultra-violet rays, and observed its spectrum four miles away, so that the mass of air intervening was as great as that between the midday summer sun and the top of the Peak of Teneriffe, from which observations of the extent of the solar spectrum have been made. The result was to show that the mercury lamp spectrum was by no means stopped when the solar spectrum stops, but that it extended to the region where ozone is most opaque. There is a strong mercury line (wavelength 2536) at about this point which was distinctly photographed. Its intensity was of course a good deal reduced relative to the visible spectrum by atmospheric scattering. But there was no evidence whatever of ozone absorption.

What conclusion can we draw? Evidently that the absorbent layer of ozone in the air is high up, and that there is little or none near the ground. It may seem at first sight that this thin and inaccessible layer of ozone, which we have learned of by a chain of reasoning not less conclusive than direct observation, is a matter of little importance to man and his welfare. There could be no greater mistake. It acts as a screen to protect us from the ultra-violet rays of the sun, which without such a protection would probably be fatal to our eyesight: at least if one may judge from the painful results of even a short exposure to such rays, which those who have experienced it are not likely to forget.

\title{
The Future of the Iron and Steel Industry in Lorraine.
}

\section{By Prof. H. C. H. Carpenter, F.R.S.}

$\mathrm{D}^{\mathrm{w}}$ URING the spring of last year two Commissions were appointed by the Minister of Munitions to visit and report upon certain steelproducing areas in Western Europe. One of them visited the steel works in Lorraine and certain parts of the Saar Valley, the other journeying to the occupied areas of Germany, Luxemburg, and certain parts of France and Belgium. The NO. 2645 , VOL. IO5] former was under the charge of Sir William Jones, and included Messrs. Percy Cooper, Rowland Harding, and Cosmo Johns, while the latter was entrusted to Dr. F. H. Hatch, who had with him Messrs. L. Ennis, James Henderson, and Richard Mather. The Commissions were absent about three weeks. The terms of reference to them were the same and were to ascertain :-- 
(a) The character and extent of the technical and other developments which had taken place during the war, with special reference to the steps taken for the development of munitions output.

(b) The present condition of plant and machinery.

(c) The prospects of these areas either as competitors with or markets for British industries.

(d) The developments in fuel economy in the steel trades of these areas.

The reports furnished by the Commissions were printed in the first instance as confidential documents by the Ministry of Munitions, but have now been made public. That of the Commission which visited Lorraine and the Saar Valley is the more complete and interesting in that it throws light on the possibilities of development of the iron- and steel-producing area, which, as a result of the war and the Peace Treaty, has passed from German to French ownership.

The view of the Commission is that the acquisition by the French of these areas should be of advantage to British industries on the whole, and that while France may become a competitor with Britain in so far as her surplus steel production is concerned, taking the place of Germany to some extent, it will not be until the destroyed works have been reconstructed and full production has been reached in a period which it estimates at from three to five years. As a result of the war, France has replaced Germany as the possessor of the largest iron-ore supplies in Europe, her reserves having been increased by more than $2,000,000,000$ tons, making them now about four times those of Germany. Before the war they were approximately the same.

Whereas France's production of pig iron in I9I 3 was about 5,000,000 tons, with her new possessions in Lorraine and the Saar Valley she is in a position to produce I I, OoO, ooo tons annually. Prior to the war German steel makers frequently complained of the difficulty of obtaining adequate supplies of foreign ores, and this is regarded by many as one of the chief causes of the war, since they hoped thereby to obtain possession of France's ore reserves. The Commission states that whereas in I9I3 Germany produced $27,000,000$, and France $2 x, 000,000$, tons of iron ore, it estimates future production to be in the ratio of Germany 7,000,000 to France 42,000,000 tons. It would appear that outside France Germany can expect to obtain ore only from Sweden or Spain, but as both these countries are actively developing their steel industries they will probably not have very much to spare.

With regard to coal, however, France's position is by no means so satisfactory. Her pre-war production was about 40,000,000 tons, and her consumption $60,000,000$ tons, the balance being obtained from Great Britain, Belgium, and Germany.

The control by France of the coal of the Saar Valley area is estimated to enable her to produce twice the tonnage obtained from the Valenciennes district. This would mean an addition of I 7,000, oo tons to the annual output, which nearly NO. 2645 , VOL. IO5] meets the deficit. The Commission states, however, that the ideal of the French iron and steel makers in the Lorraine area at the present time is that means should be devised whereby a reciprocal business may be done with Great Britain by their supplying basic pig iron in exchange for furnace coke or coking coal. If the anticipated output of oven coke in this country is realised there should be some to spare, but the difficulties of transport, transhipment, etc., and the resultant breakage are serious factors to be considered. Possibly the solution of the present problem may be found in the erection of coke ovens in Lorraine close to the furnaces, and in the production of coke on the spot from a mixture of Saar coal and Durham coking coal. The supply of the latter cannot take place until better and cheaper means of transport are available.

The Commission states that France dreads the present position of dependence upon Germany for coke supplies, since, although the Peace Treaty gives her control of the Saar Valley coalfield for, at any rate, fifteen years, the fact remains that under existing conditions the works must have coal or coke from Westphalia for their blast furnaces. The coke obtained from Saar coal is apparently unsatisfactory, so that so long as this position continues French industry will remain to a great extent at the mercy of the Germans, a position the French are, naturally, most anxious to avoid. It is true that Germany will want iron ore from Lorraine, but she will not be so entirely dependent upon this one source of supply as the Lorraine works will be upon Germany for coke, unless some means are provided to enable them to obtain coke from elsewhere or to produce what they need from Saar coal and imported coking coal.

Various schemes for improved transport are under contemplation by France. The construction of a canal to Dunkirk from the Briey district known as the "Canal du Nord et de 1'Est" has been under consideration for a long time. This would take at least five years to complete, and is not generally favoured by the French steel makers in Lorraine owing to the enormous cost of construction and the great difficulties to be overcome in cutting it through the densely populated industrial areas of Northern France. The scheme most favoured is that known as the canalisation of the Moselle from Coblenz to Thionville and thence to Metz, coupled with free navigation of the Rhine to Rotterdam or by canal from the Rhine to Antwerp via Maastricht. Either of these schemes, it is considered, would be much cheaper and more quickly operative than the canal to Dunkirk. The estimate of the cost of the Moselle Canal scheme would be between $15,000,000 l$. and $20,000,000 l$., and it is calculated that the construction could be completed in three years. Plans for this scheme are in the hands of the French authorities. The strong feeling in favour of this scheme to enable reciprocal business to be done with Great Britain is accentuated by the treatment 
accorded to the Lorraine steel works by Germany in the matter of coke supplies, since the Germans have failed to carry out their obligations under the terms of the Peace Treaty, and have delivered only about one-third of the tonnage promised, notwithstanding the fact that there are large stores of furnace coke in Westphalia. Since Great Britain has been short of basic pig iron for a long time, and there is every prospect of the shortage continuing, some such reciprocal arrangement as that put forward might be of advantage to both countries.

The Commission states that there is no doubt that economy in fuel consumption is very fully effected, owing to the absence of cheap and suitable fuel and the dependence of the works upon Westphalian coke. All the waste heat is utilised at every works. The blast-furnace gas is suitably cleaned and fully absorbed. The works at Homécourt may be cited as an instance. Before the war they were producing 9000 tons of pig iron and 7000 tons of steel weekly, and they used only 280 tons of coal, all the remaining power being produced from blast-furnace gas. This is quite typical. The molten metal is taken from the blast furnaces to the mixers in the adjacent steel works and the sensible heat thus utilised.

A study of the report leaves the impression that the development of the iron- and steel-producing areas in Lorraine which have passed from German to French management presents problems which will call for patient consideration, dispassionate counsel, and scientific treatment, if they are to be surmounted successfully. The formidable position which Germany had built up between I87 I and I9I4 has been lost to her by the war. It remains to be seen what France will make of the heritage which has passed into her hands.

\section{Obituary,}

WE regret to note that the death of $M_{R}$. JoHN W. W. DRYsdale is recorded in the Engineer for June 25 as having occurred on June 21. Mr. Drysdale was in his seventy-second year, and was one of the founders of the wellknown Glasgow firm of Drysdale and Co., Ltd. He finished his education at Glasgow University under Prof. Macquorn Rankine, and thereafter started a small works in conjunction with a fellowstudent, Mr. Lewis J. Pirrie, son of Principal Pirrie of Aberdeen. Centrifugal pumps formed their outstanding speciality from the first, and the firm has acquired a wide reputation for its products. Mr. Drysdale was a member of the Institution of Engineers and Shipbuilders in Scotland.

WE announce with great regret the death, at the Queen Alexandra Military Hospital, Millbank, of Surgeon-General W. C. Gorgas, of the U.S. Army, so well known for his work in combating yellow fever and malaria.

$$
\text { NO. } 2645 \text {, VOL. IO5] }
$$

\section{Notes.}

The Lord President of the Council, as president of the Committee of Council for Scientific and Industrial Research, has appointed Dr. J. S. Flett, at present Assistant to the Director in Scotland, to be Director of the Geological Survey and Museum. Dr. Flett succeeds Sir Aubrey Strahan, who retires this month. Mr. G. W. Lamplugh, Assistant to the Director in England, also retires.

Sir John Cadman, Mr. W. B. Hardy, and Prof. S. Young have been appointed by an Order in Council members of the Advisory Council to the Committee of the Privy Council for Scientific and Industrial Research.

IT is announced that Sir T. Clifford Allbutt is to be sworn a member of the Privy Council.

THE secretaryship of the Royal Irish Academy, vacant through the death of Prof J. A. McClelland, has been filled by the election of Prof. G. H. Carpenter.

THE Barnard medal of Columbia University has been awarded to Prof. Einstein "in recognition of his highly origina! and fruitful development of the fundamental concepts of physics through the application of mathematics."

Dr. E. Solvay has been elected an honorary member of the American Chemical Society.

The Medical Research Council has recently established at the Lister Institute of Preventive Medicine a national collection of type cultures from which biologists in general, and bacteriologists in particular, may obtain authentic strains of recognised bacteria and protozoa for use in scientific work. The scheme is under the general direction of Dr. J. C. G. Ledingham, while Dr. R. St. John Brooks has been appointed to the post of curator of the collection and Miss Mabel Rhodes to that of assistant curator. It is proposed to collect and maintain bacterial strains from all departments of bacteriology, human, veterinary, and economic, and already considerable work has been done towards the formation of a representative collection on these lines. The efforts of the staff are, however, at present particularly directed towards the securing of fully authenticated strains responsible for or associated with disease in man and animals. The bureau proposes to supply cultures on demand to all workers at home and abroad, and, as a rule, a nominal charge per culture will be made to defray postage and media. Strains sent for identification and maintenance should be accompanied by particulars as to source, date of isolation, etc. In due course a catalogue will be prepared for publication.

IN NATURE of January I last an account was given of the Cawthron Institute of New Zealand, founded for the furtherance of scientific research in relation to agriculture and other industries. The scope of the institute has since been extended by the establishment of a biological department, of which Dr. R. J. Tillyard, the eminent Australian entomologist, hitherto 